\title{
«РЫЦАРЬ БЕЗ СТРАХА И УПРЁКА» (к 110-летию со дня рождения С.С. Черникова)
}

\author{
(C) 2019 г. М.В. Бедельбаева
}

Статья посвящена жизни и научной деятельности С.С. Черникова (1909-1976) - известного археолога, исследователя древней истории Восточного Казахстана, 110-летие со дня рождения которого отмечается в этом году. С 1947 по 1972 гг. он являлся бессменным руководителем Восточно-Казахстанской археологической экспедиции. Фундаментальные работы С.С. Черникова внесли существенный вклад в разработку хронологии памятников эпохи бронзы региона и определение общих контуров социально-экономической истории древних обществ. Крупным открытием и знаковым памятником, вошедшим в мировой фонд археологии, стали его раскопки известного «Золотого кургана» в Шиликтинской долине.

Ключевые слова: археология, С.С. Черников, Восточный Казахстан, эпоха бронзы, древняя металлургия, ранние кочевники, курган

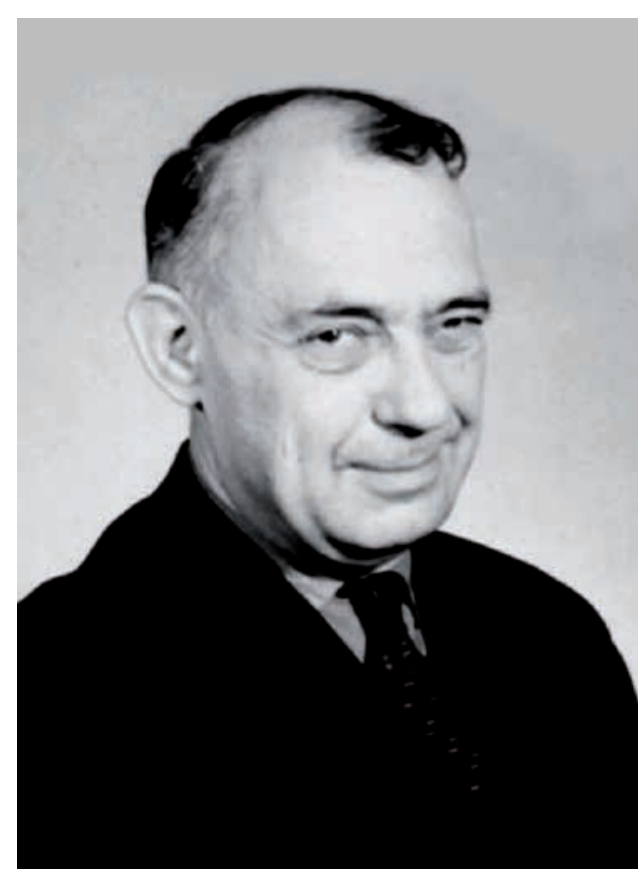

Рис. 1. Сергей Сергеевич Черников. 1960-е годbl

Fig. 1. Sergey S. Chernikov. 1960s
Дождливым октябрём 1976 г. в стенах обычной коммунальной ленинградской квартиры, где проживали пять семей, завершил свой жизненный путь учёный, археолог, доктор исторических наук, посвятивший свою жизнь изучению древней истории Восточного Казахстана и открывший знаменитых золотых «летящих оленей» долины Шиликты. Скромный человек, он покинул этот мир тихо без громких прощаний. Авторитетный научный журнал «Советская археология» не счел необходимым разместить на своих страницах некролог памяти ученого, как это полагалось в те годы. Его памяти, юбилейным датам не посвящали научных конференций ни тогда, ни в наше время, как это принято в отношении многих из тех блестящих археологов, с кем он работал вместе в Ленинградском отделении Института археологии АН СССР. 
Сергей Сергеевич Черников... Это имя с особым уважением произносят в Казахстане и на заседаниях научных форумов, и в студенческих аудиториях, и в полевых лагерях археологов. Учёный, который стоял у истоков создания ВосточноКазахстанской археологической экспедиции * [*ВКАЭ - прим. авт.] и являлся её бессменным руководителем, пока не перестало биться его сердце. Его находки и открытия были на слуxy, его суждения вызывали споры, его лекции воспринимались студентами с неизменным интересом, а тексты его авторства в фундаментальных академических изданиях по истории древнего Казахстана, вышедших в 50-70-е гг. прошлого столетия, служили основой для формирования профессиональных компетенций специалистов-историков.

Имя С.С. Черникова стоит в одном ряду с именами А.Н. Бернштама, С.И. Руденко, М.П. Грязнова и других представителей ленинградской археологической школы, полевые и теоретические исследования которых внесли значительный вклад в развитие археологии Казахстана и подготовку национальных научных кадров. В г. Ленинграде - центре академической и вузовской науки - проводили свои первые научные изыскания основатели казахстанской археологической школы А.Х. Маргулан, К.А. Акишев, М.К. Кадырбаев, А.М. Оразбаев.

С.С. Черников, в отличие от М.П. Грязнова и других ленинградских авторитетных специалистов, не осуществлял руководство диссертационными исследованиями казахстанских археологов, но, несомненно, оказал значительную помощь в их профессиональном становлении. Он выступил официальным оппонен- том при защите К.А. Акишевым 4 декабря 1953 г. в Ленинграде первой в истории казахстанской археологии кандидатской диссертации. В рамках ВКАЭ под руководством С.С. Черникова приобретали первый опыт полевой экспедиционной деятельности М.К. Кадырбаев [будучи студентом Ленинградского госуниверситета - прим. авт.], А.М. Оразбаев и А.Г. Максимова [в качестве руководителей отрядов ВКАЭ - прим. авт.].

В Казахстане его знали многие и понятно почему весть о безвременной кончине учёного не оставила ученых равнодушными. В отличие от хранивших молчание центральных академических изданий СССР в журнале «Известия АН Казахской ССР» был опубликован некролог, написанный М.К. Кадырбаевым. Учёный отмечал, что монографии и научные статьи С.С. Черникова явились весомым вкладом в изучение древней истории степных племен Казахстана и выражал сожаление, что прервалась работа над главным трудом жизни ученого - «Очерки древней истории Восточного Казахстана» [Кадырбаев, 1976 , с. 88-89].

Чувство потери осталось не только у коллег учёных, но и у многих, кто не связал свою жизнь с археологией, но прошёл через экспедиции вместе с С.С. Черниковым, прежде всего, у студентов и преподавателей Усть-Каменогорского педагогического института. Доктор исторических наук, профессор Н.В. Алексеенко позднее напишет в своих воспоминаниях: «Нет, далеко не все, кто работал с ним, стали учеными. Но все, кого судьба порадовала общением с этим человеком, на всю жизнь сохранили ощущение близости с ученым, гражданином, нашим Сергеем Сергеевичем» [Алексеенко, 2011, с. 83]. 
Думается, что это ощущение близости рождалось вследствие открытости С.С. Черникова как человека, его оптимизма и мужественного характера, который позволял преодолевать непростые жизненные испытания, среди которых были и опалённые войной годы. С.С. Черников ушёл на войну добровольцем в народное ополчение Ленинграда, хотя мог попытаться получить бронь и продолжать свои научные изыскания в эвакуации, тем более, что в предвоенные годы он сделал серьёзный задел для работы над диссертацией. Именно гражданская позиция учёного особенно впечатляла коллег. Поэтому мы сочли уместным вынести в заголовок биографического очерка о Сергее Сергеевиче слова известного археолога Л.Р. Кызласова, тоже фронтовика, который подчёркивал, что ВКАЭ была создана «...истинным рыцарем без страха и упрека, защитником Ленинграда в дни блокады, капитаном С.С. Черниковым» [Кызласов, 2017, с. 72].

Казалось, военная служба была с детства предопределена будущему учёному - он родился в 1909 году в г. Белгород в семье капитана 6-го Финляндского стрелкового полка императорской армии С.Ф. Черникова. Но его отец умер в 1911 г. и главную роль в воспитании будущего гражданина сыграла мама - учитель школы, вместе с которой Сергей Сергеевич переехал в г. Санкт-Петербург, ставший для него впоследствии главным городом жизни.

После окончания в 1926 г. 101-й средней школы С.С. Черников учился в Ленинградском университете на факультете языкознания и материальной культуры по египтологическому уклону. В 1930 г. он перевелся на музейно-краеведческое отделение Ленинградского историколингвистического института, где получил специальность музейного работника по истории доклассового общества. Окончив обучение в институте, с 1932 г. молодой специалист работал инспектором научных учреждений в г. Новосибирск, а затем, вернувшись в Ленинград, служил научным сотрудником в Русском музее, преподавал историю в школе и Доме Красной Армии, был коллектором в экспедициях Центрального геологоразведочного института, с которым сотрудничал и во время учёбы в 1930-1931 гг. [Длужневская, 2011, c. 234-235].

Опыт работы в геологических экспедициях и историческое образование стали определяющими факторами, благодаря которым С.С. Черников в 1935 г. был принят на должность младшего научного сотрудника в Государственную академию истории материальной культуры [ГАИМК, с 1937 г. Институт истории материальной культуры АН СССР - прим. авт.]. Так он окончательно связал свою жизнь с археологией. Учёный будет верен не только профессии, но и своему научному учреждению, где в дальнейшем проработает всю жизнь. Такая же последовательность и преданность будут отличать его и в выборе объекта научных исследований, каковым навсегда останется древняя история Восточного Казахстана.

В 1935 г. С.С. Черников впервые приехал в Казахстан в качестве начальника археологического отряда Казахстанской экспедиции ГАИМК под руководством А.А. Иессена, а в 1937-1938 гг. уже действовал в статусе руководителя всей экспедиции [Длужневская, 2011, с. 34]. Впрочем, должности начальника и руководителя тогда имели скорее официальный 
статус, так как фактически С.С. Черников осуществлял археологическую разведку единолично, объезжая степь верхом на лошади и с благодарностью принимая гостеприимство жителей казахских аулов, ведь именно их поддержка очень помогала исследователю при весьма скромном финансировании работ [Алексеенко, 2011, с. 81].

Перед экспедицией, организованной в интересах народного хозяйства ресурсами нескольких организаций - ГАИМК, Союзникельоловоразведкой (трест «Калбаолово») и Главзолоторазведкой (Джеламбетская партия), ставилась задача изучения древних выработок на золото, олово и медь в Восточном Казахстане и Кокчетавской области Северного Казахстана. В ходе раскопок, проведённых С.С. Черниковым в районах Калбинского и Нарымского хребтов, были исследованы древние выработки и полученные результаты свидетельствовали, что в верховьях р. Иртыш в конце II - начале I тыс. до н.э. существовал один из крупных очагов древнего горного дела и первобытной металлургии.

Краткая информация о раскопках С.С. Черникова была опубликована в 1939 г. в рамках «Обзора полевых археологических исследований ИИМК Академии наук СССР в 1938 г.». Тогда же была издана первая научная статья С.С. Черникова - «Древняя добыча меди в верховьях Иртыша». Однако основные результаты работы он сможет обобщить и опубликовать только после войны, защитив в 1947 г. кандидатскую диссертацию и издав в 1949 г. в г. АлмаАта свою первую монографию «Древняя металлургия и горное дело Западного Алтая». Первенство учёного в данной проблематике долгие годы было неоспоримым и в 1967 г. К.А. Акишев особо отметит: «Работа С.С. Черникова до сих пор является одним из первых в СССР трудов, специально посвященных развитию металлургии и горного дела в древности» [Акишев, 1967, с. 65].

Испытания периода Великой Отечественной войны 1941-1945 гг. капитан С.С. Черников - «рыцарь без страха и упрёка» - пройдёт с честью: его ратный путь отмечен 15-ю орденами и медалями, среди которых орден Красной Звезды и Отечественной Войны II степени, медали «За оборону Ленинграда» и «За взятие Берлина».

Командир дивизии, в которой служил С.С. Черников, генералмайор артиллерии Д.И. Скоробогатов в своих мемуарах дал высокую оценку действиям учёного на фронте: «Надо сказать, что большинство офицеров химической службы кроме своих непосредственных обязанностей выполняли работу и не по специальности. Так, начальник химической службы нашей дивизии капитан С.С. Черников, ныне доктор исторических наук, сумел найти свое место среди офицеров оперативного отдела штаба дивизии. Это был почти бессменный оперативный дежурный, который мог в любой момент толково доложить обстановку на участке дивизии; он оформлял оперативную карту, а при передвижении штаба дивизии вел колонну штабных машин. Его часто можно было видеть и на наблюдательном пункте командира дивизии, где капитан помогал в организации и ведении разведки, в управлении огнем» [Скоробогатов, 1976].

Именно в годы войны в критических ситуациях особо ярко проявились организаторские способности С.С. Черникова, его инициативность, 
решительность, ответственность и умение работать с людьми. Приведём в подтверждение наших слов выдержку из наградного листа к его первому ордену Красной Звезды: «При прорыве обороны противника в районе Долгая Нива - Пустой Конец левый берег реки Нарва 11.2.1944 г. 1426 легко-артиллерийский полк имел задачу в течение ночи занять огневые позиции прямой наводкой на 150-200 метров от переднего края. Получив задачу проконтролировать в отдельности каждое орудие и оказать помощь командирам подразделений в исполнении боевой задачи, капитан Черников, несмотря на трудности условия местности, сильный оружейно-пулеметный, артиллерийско-минометный огонь воодушевлял бойцов, организовывал их личным примером, помог командирам подразделения выполнить в срок боевую задачу...» [Наградной лист].

После демобилизации в 1946 г. C.С. Черников вернулся на работу в Ленинградское отделение ИИМК [с 1959 г. Ленинградское отделение Института археологии АН СССР - прим. авт.]. Сначала он занимался научными исследованиями в секторе бронзы и раннего железа, а с 1951 г. и до своей кончины - в секторе Средней Азии и Кавказа [Академическая археология, 2013, с. 394]. В 1947-1972 гг. он будет регулярно приезжать в Казахстан для проведения археологических исследований в качестве руководителя ВКАЭ.

Организационные способности и исследовательский опыт С.С. Черникова оказались особенно востребованы в Казахстане в первые послевоенные годы. В республике активно развивалась научная инфраструктура, была создана Академия наук Казахской ССР, разворачивались широкомасштабные археологические исследования. Усилиями А.Х. Маргулана в 1946 г. был образован сектор археологии Института истории, археологии и этнографии им. Ч.Ч. Валиханова [далее ИИАЭ АН КазССР - прим. авт.], приступила к работе Центрально-Казахстанская археологическая экспедиция. Летом 1947 г. С.С. Черников провёл первый послевоенный полевой сезон ВКАЭ. Вместе с тем, когда А.Х. Маргулан вынужден был на время отказаться от руководства сектором, ленинградский учёный с 1 декабря 1947 г. был назначен на должность заведующего сектором археологии по совместительству на полставки [Бейсенов и др., 2017, с. 34].

Выполняя функции руководителя сектора археологии, С.С. Черников уделял внимание не только работе ВКАЭ, но, в целом, организации археологических исследований в Казахстане, и опубликовал в 1950 г. в «Известиях АН Казахской ССР» статью «Основные проблемы археологического изучения Казахстана». В данной статье, проанализировав работу действовавших на тот момент четырёх археологических экспедиций, включая ВКАЭ, он сформулировал основные задачи дальнейших археологических исследований в Казахстане в свете изучения проблем палеолита и неолита, эпохи бронзы, племенных союзов ранних кочевников и варварских государств [Бейсенов и др., 2017, с. 43]. Системный поход к изучению культурноисторического наследия Казахстана будет характерен для учёного и в дальнейшем. Так, выступая рецензентом первого в СССР уникального издания, каковым стала опубликованная в 1960 г. «Археологическая 
карта Казахстана», С.С. Черников не ограничился рядом обоснованных замечаний по содержанию издания, но и изложил своё видение дальнейших задач археологической науки Казахской ССР. Среди них - разработка республиканского перспективного плана археологических работ, сплошное территориальное обследование республики и плановая работа пяти экспедиций (Западно-Казахстанской, Центрально-Казахстанской, Восточно-Казахстанской, Семиреченской и Южно-Казахстанской) [Черников, 1963, с. 317].

После того как 25 февраля 1950 г. А.Х. Маргулан вновь был утверждён в должности заведующего сектором, С.С. Черников получил возможность полностью сосредоточиться на организации работы ВКАЭ.

Экспедиция являлась совместным проектом ИИМК АН СССР и ИИАЭ АН КазССР. Также деятельность экспедиции финансировалась Казгидроэнергостроем, так как одной из главных задач являлось обследование зоны затопления Бухтарминской ГЭС [в долине р. Иртыш от устья Бухтармы до озера Зайсан - прим. авт.], а в 1955 г. - зоны затопления Шульбинской ГЭС [от УстьКаменогорска до ст. Шульба - прим. авт.]. Работа экспедиции носила комплексный характер, ставя задачу максимально широкого охвата полевыми исследованиями памятников различных исторических периодов. На это была нацелена и организационная структура экспедиции, включавшая палеолитический, андроновский и ранне-кочевнический отряды [так они назывались в документации экспедиции - прим авт.].

В целом, в 1947-1956 гг. участниками экспедиции под руководством С.С. Черникова была продела- на огромная работа, к наиболее значимым результатам которой следует отнести раскопки палеолитической стоянки Пещера [самой древней на тот момент стоянки на территории Казахстана - прим. авт.], неолитического поселения у деревни УстьНарым, андроновских поселений у деревень Мало-Красноярка, Трушниково, аула Канай, могильников эпохи ранних кочевников в долине Шиликты, у озера Сарыколь, в районе сёл Кулажорга, Баты и других. Результативными были и археологические обследования, позволившие нанести на карту большое количество ранее не известных археологических объектов. Всего по данным С.С. Черникова с учётом довоенных экспедиций было зарегистрировано 3045 курганов, 33 пункта древних выработок, 21 пункт наскальных изображений, 6 пунктов находок палеолитических орудий (из них одна стоянка), 8 пунктов находок неолита (из них две стоянки) и 11 поселений андроновской культуры [Черников, 1960, с. 140].

Результаты работ ВКАЭ регулярно освещались С.С. Черниковым в научных статьях, но разносторонний характер полученных материалов мотивировал исследователя задуматься о воплощении идеи, реализацию которой он считал своим долгом - написание труда «Очерки древней истории Восточного Казахстана». Работа над книгой велась в плановом порядке в рамках проблематики исследований сектора Средней Азии и Кавказа ЛО ИИМК АН СССР [Гурина, 1958, с. 113].

В силу своих научных интересов учёный в первую очередь систематизировал и проанализировал материал, полученный на поселениях андроновской культуры. Немаловажным в определении приоритетов, 
как мы полагаем, являлось взаимодействие с М.П. Грязновым, который возглавлял сектор. В конечном счёте, многолетний авторский труд увенчался изданием новой монографии С.С. Черникова «Восточный Казахстан в эпоху бронзы» [Черников, 1960]. Во Введении автор указал, что рассматривает данную монографию как часть будущих «Очерков...» и в этом контексте публикация представлялась как запланированный шаг на намеченном пути, как один из очерков.

Вместе с тем, не исключено, что решение С.С. Черникова поторопиться с публикацией книги было мотивировано конкуренцией за научное первенство с А.Г. Максимовой, которая в составе ВКАЭ до 1954 г. руководила андроновским отрядом и выполнила основной объём работы, связанный с раскопками поселений эпохи бронзы. Надо отдать должное Анне Георгиевне и Сергею Сергеевичу - они не предавали публичной огласке случившийся между ними конфликт. Детали этой ситуации стали известны после публикации А.Е. Рогожинского, основанной на материалах из личного дела А.Г. Максимовой [Рогожинский, 2017, с. 146-148]. Ученик А.Г. Максимовой видит в данном конфликте, в первую очередь, вину С.С. Черникова, с чем трудно спорить, но вывод о том, что этот инцидент обнажил глубокие противоречия между «центром» и «периферией», представляется нам преувеличением. Суть случившегося была сугубо в конфликте научных интересов двух учёных, в ситуации, когда они разрабатывали в разных учреждениях (союзном и республиканском) похожие плановые темы на основе одних и тех же археологических материалов. С.С. Черников работал над плановой темой в ЛО
ИИМК АН СССР, а А.Г. Максимова в ИИАЭ АН КазССР была исполнителем плановой темы «История Восточного Казахстана в эпоху бронзы» и готовила к защите диссертацию по данной теме. Объектом исследования двух учёных являлись полевые материалы, многие из которых в ходе раскопок непосредственно получала А.Г. Максимова, но действуя в составе ВКАЭ, руководимой С.С. Черниковым. Понятно, что С.С. Черников использовал в полном объёме право руководителя ВКАЭ на работу с полученными материалами, что вызывало небезосновательные опасения у А.Г. Максимовой в том, удастся ли ей обеспечить научное первенство, без которого диссертация утратила бы свою актуальность. Своеобразной «страховкой» для исследовательницы явилось копирование без санкции руководителя экспедиции материалов, высылаемых в Ленинград, и «работа на опережение»: быстрое написание текста диссертации и его опубликование в «Трудах ИИАЭ АН КазССР» до выхода монографии С.С. Черникова [Максимова, 1959]. Однако защита диссертации А.Г. Максимовой состоялась только после издания C.С. Черниковым монографии. Эта «задержка» и тот факт, что С.С. Черников опубликовал в своей монографии сводную археологическую карту Семипалатинской и ВосточноКазахстанской областей, составленную А.Г. Максимовой, признав лишь причастность исследовательницы к работе над картой, а не её авторство, являются далеко не лучшими событиями в жизни учёного. Правда, насколько нам известно, это единственный случай такого рода в научной биографии С.С. Черникова, который, напротив, всегда помогал молодым исследователям. 
Интересно, что в дальнейшем научном соревновании двух исследователей ближе к истине оказалась всё же А.Г. Максимова. Мы имеем в виду оценку в научном сообществе предложенных учёными по итогам работы ВКАЭ вариантов периодизаций андроновской культуры Восточного Казахстана. Большинство археологов признали правомерность выделения А.Г. Максимовой двух этапов - федоровского и позднебронзового. В то же время С.С. Черников, приняв за основу предложенные С.В. Киселевым общие хронологические рамки андроновской культуры, выделил четыре этапа в её развитии: I - устьбуконьский; II - канайский (XVIXII вв. до н.э.), III - малокрасноярский (XII-IX вв. до н.э.), IV - трушниковский (IX-VIII вв. до н.э.). Такая периодизация вызвала серьёзные возражения М.П. Грязнова, М.Н. Комаровой, В.С. Сорокина [Кузьмина, 2008, c. 72].

Особенно категоричен был в своих суждениях ленинградский учёный В.С. Сорокин, руководивший Западно-Казахстанской экспедицией. В своей рецензии он положительно оценил монографию С.С. Черникова только как источник информации о многолетних раскопках ВКАЭ, сделав вывод, что «...исследовательская её часть слаба, а оригинальные выводы автора не только не обогащают науку, но подчас дают неправильную ориентировку» [Сорокин, 1962, с. 130]. Однако, С.С. Черников и в ответе на рецензию В.С. Сорокина, и в дальнейших исследованиях будет настаивать на своей точке зрения.

Несмотря на дискуссионность выводов С.С. Черникова, его авторитет среди исследователей эпохи бронзы был высоким. В частности, именно он выступил с основным докладом на Всесоюзном совещании по вопросам андроновской культуры в декабре 1964 г. в Ленинграде. В этом же году в рамках работы ВКАЭ им были продолжены полевые исследования объектов эпохи бронзы: в селе Предгорное близ г. Усть-Каменогорска раскопан андроновский могильник [Бентович, 1966, с. 138]. Вместе с тем, данное научное направление к этому времени уходит для учёного на второй план. Точка будет поставлена 29 мая 1970 г. на защите докторской диссертации С.С. Черникова «Восточный Казахстан в эпоху неолита и бронзы», на которой официальными оппонентами выступили О.Н. Бадер, Д.А. Крайнов и А.И. Тереножкин. Часть диссертации, посвящённая эпохе бронзы, представляла собой переработанный вариант ранее опубликованной монографии, где автор оставил без существенных изменений свои основные выводы по вопросам периодизации андроновской культуры Восточного Казахстана. Поэтому после выступления соискателя вновь разгорелась дискуссия о правомерности выделения усть-буконьского и других этапов, что, в целом, не повлияло на положительные итоги защиты и Учёный совет ИА АН СССР единогласно присудил С.С. Черникову учёную степень доктора исторических наук [Успехи среднеазиатской археологии, 1972, с. 61].

Докторской диссертацией C.C. Черников завершил и многолетние исследования неолитических памятников в Восточном Казахстане. Нельзя не отметить тот факт, что систематические исследования в данном направлении в Казахстане были начаты с 1950 г. палеолитическим отрядом ВКАЭ [руководители Э.Р. Рыгдылон, И.И. Гохман, И.М. Павлюченко - прим. авт.]. В ходе работ были 
впервые раскопаны объекты палеолита и неолита на территории Казахстана, в том числе и неолитическое поселение у деревни Усть-Нарым. В 60-е годы ХХ века в ЛО АН СССР C.С. Черников был исполнителем ряда тем, связанных с анализом полученных ВКАЭ неолитических материалов. Так, в 1960-1962 гг. в рамках серии «Свод археологических источников» им велась работа над книгами «Неолитические памятники Казахстана» (совместно с А.А. Формозовым) и «Дюнные стоянки Казахстана (неолит и энеолит)» (по неизданным коллекциям таких памятников, как Семипалатинские дюны, МалоКрасноярка, Капрак-коль, Тургай). Данные книги не были подготовлены к публикации и С.С. Черников далее продолжил работу над темами «Карта неолитических памятников Казахстана» и «Поселение Усть-Нарым», которые, в конечном счёте, переросли в сводную работу по неолиту Казахстана, завершённую в 1968 г. [Бентович, 1970, c. 122]. К сожалению, свой труд «Неолит Казахстана» исследователь не опубликовал, но после защиты им докторской диссертации данная рукопись была введена в научный оборот. Её, в частности, использовала Л.А. Чалая, аспирантка Л.Р. Кызласова, при подготовке кандидатской диссертации на тему «Неолит Северо-Восточного и Центрального Казахстана», а С.С. Черников выступил официальным оппонентом на защите диссертации [Чалая, 1971].

Занимаясь рутинной, повседневной работой в экспедициях, С.С. Черников, конечно же, как и каждый археолог, мечтал о ярких уникальных находках. Нельзя сказать, что изученные им артефакты периода неолита и эпохи бронзы не были важными и резонансными. Но настоящая удача ждала учёного в третьем направлении исследований ВКАЭ - изучении памятников эпохи ранних кочевников. Результатом стали раскопки знаменитого Золотого кургана в долине Шиликты. Сейчас казахстанцев уже не удивить находками такого уровня, так как археологические раскопки К.А. Акишева, 3. Самашева, А.Т. Толеубаева, А.3. Бейсенова значительно продвинули вперёд изучение сакской эпохи и открыли миру великолепные образцы богатого культурно-исторического наследия Великой Степи. Но на рубеже 50-60-х гг. прошлого столетия открытия С.С. Черникова были настоящей сенсацией.

Археологическую разведку в Шиликты С.С. Черников провёл ещё в 1949 г., в результате чего в центре долины был обнаружен могильник из 57 курганов, а в других местах долины ещё четыре могильника. В этом же году при раскопках кургана № 7 был найден ряд изделий из золота, выполненных в характерном зверином стиле. Однако, наиболее сенсационные находки предметов раннесакской культуры были получены С.С. Черниковым в 1960 г. в ходе раскопок кургана № 5, относящегося по своим размерам к «царским» элитным курганам, который будет впоследствии назван «золотым» в силу значительного количества обнаруженных изделий древних мастеров, изготовленных из листового золота. Среди находок были и украшавшие колчан для стрел искусно выполненные 30лотые нашивные бляшки в виде «летящих оленей» - так назвал позу изображённых животных С.С. Черников [Черников, 1965, с. 31]. Уникальные находки были переданы на хранение в ГосЭрмитаж, где находятся и в настоящее время. 
В 1971-1972 гг. в Шиликты силами ВКАЭ будут проведены раскопки курганов № 35, 2-а, 10, однако, таких ярких результатов, какие принёс полевой сезон 1960 г., больше получить не удастся. В последующем финансирование раскопок ВКАЭ на союзном уровне будет прекращено и исследования памятников долины Шиликты будут продолжены в 2003 г. археологической экспедицией КазНУ им. аль Фараби под руководством А.Т. Толеубаева.

Итоги раскопок 1960 г. и их научную интерпретацию С.С. Черников представил в изданной в 1965 г. научно-популярной книге «Загадка Золотого кургана. Где и когда зародилось “скифское искусство”». Проблема генезиса скифо-сарматского звериного стиля в искусстве была предметом научных дискуссий, в рамках которых сформировались три гипотезы о месте происхождения данного стиля - центральноазиатская, переднеазиатская и полицентрическая. Находки С.С. Черникова усилили позиции сторонников центральноазиатской гипотезы. Как отмечал К.А. Акишев, золото Шиликты «...послужило причиной возрождения, но уже в новом варианте, старой геродотовской версии о приходе скифов с востока» [Акишев, 1967, с. 71]. С.С. Черников поддержал гипотезу А.Н. Бернштама, согласно которой саки Средней Азии и Казахстана были прямыми потомками племен поздней бронзы, обитавших на этой территории. Развивая идеи, изложенные в своей книге, С.С. Черников, выступил на Третьей конференции по скифо-сибирской археологии [Москва, декабрь 1972 г. - прим. авт.] и обосновал вывод о местных корнях происхождения «звериного стиля», возводя его к неолитической эпохе [Скифо-сибирский звериный стиль, 1972, с. 6].

В конце 60-первой половине 70-х гг. прошлого столетия основной научной темой для С.С. Черникова становится исследование процессов классообразования и политогенеза у ранних кочевников. Эта тема разрабатывалась им в рамках пятилетнего плана ЛОИА АН СССР (19711975 гг.), согласно которому научным направлением работы отделения являлось исследование исторических форм и особенностей развития и смены общественно-экономических формаций [Хлобыстина, 1976, с. 126127]. Помимо ряда публикаций в ма-

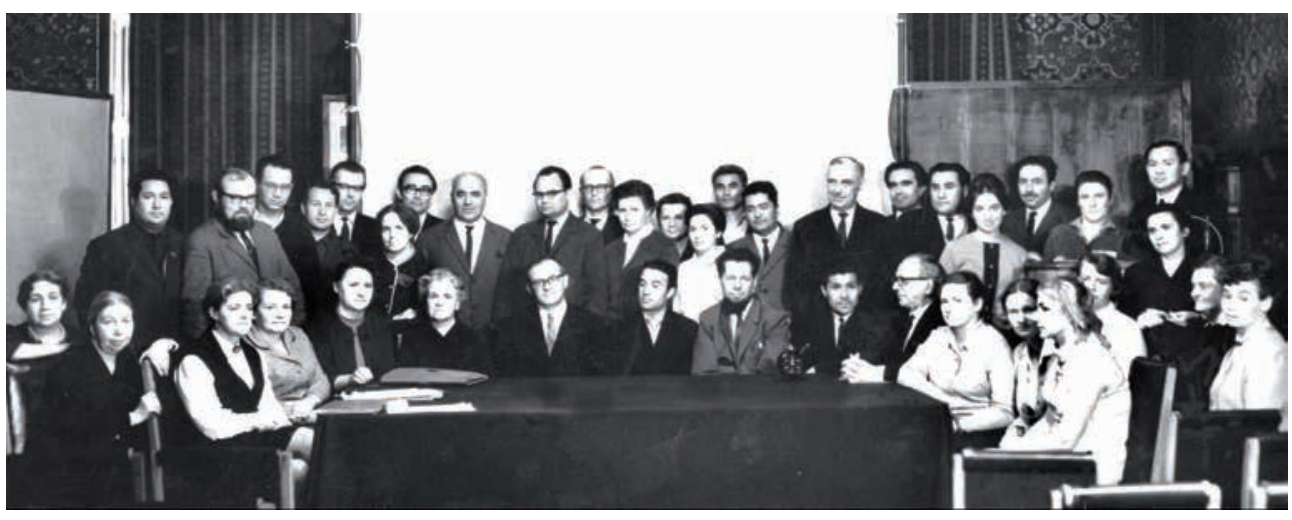

Рис. 2. На V совещании по проблемам археологии Средней Азии. 06.04.1968 2.

Fig. 2. At the 5 meeting on the problems of archaeology of Central Asia. 04/06/1968 
териалах различных конференций и сборниках статей он активно представлял итоги своих исследований, выступая с докладами на заседаниях сектора Средней Азии и Кавказа ЛО ИА АН CССР: «Ранние кочевники Восточного Казахстана» $(05.02 .1971$ г.), «Хронология памятников ранних кочевников Восточного Казахстана» (28.04.1972 г.), «Социальный строй ранних кочевников Восточного Казахстана и их политическая история» (12.01.1973 г.).

В отличие от М.П. Грязнова, который оставался одним из наиболее последовательных сторонников ограниченности социального развития ранних кочевников военнодемократическим уровнем, С.С. Черников выявлял про-

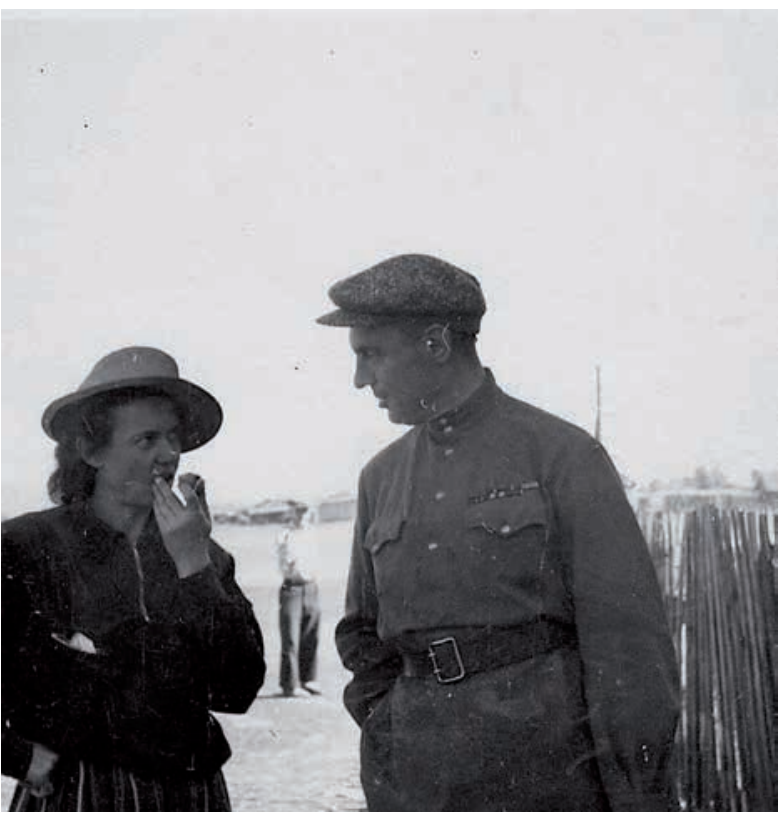

Рис. 3. С.С. Черников с директором ВосточноКазахстанского областного историкокраеведческого музея Р.П. Столбовой. УстьНарым, 1952. Фото из архива ВКОИКМ

Fig. 3. S. Chernikov with the director of the East Kazakhstan Regional Museum of History and Local Lore R.P. Stolbova. Ust-Narym, 1952. Photo from the Museum's archive цессы постепенной классовой дифференциации и возникновения государства у номадов. Он выделял период «военной демократии» (VII-IV вв. до н.э.) и «время примитивной государственности в степях», начиная с позднескифского (IV-III вв. до н.э.) и, особенно, с хунно-сарматского периодов.

Завершая характеристику научных исследований С.С. Черникова, нельзя не отметить и его значительный вклад в развитие краеведения и музейного дела в Восточном Казахстане. Длительным и плодотворным было сотрудничество учёного с Усть-Каменогорским областным музеем [ныне Восточно-Казахстанский областной историко-краеведческий музей - прим. авт.]. С.С. Черников в своей монографии специально под-

черкнул, что считает своим долгом особо поблагодарить сотрудников музея за неизменную помощь в работе [Черников, 1960, с. 9]. В свою очередь музейные работники за многое благодарны учёному - значительная часть коллекции музея, который является одним из самых крупных в Казахстане, была сформирована в результате раскопок, проведённых ВКАЭ, а знаменитый золотой олень Шиликты стал официальной эмблемой музея.

C.C. Черников успел многое сделать, стал известным учёным, но остался при этом доступным в общении, открытым, доброжелательным человеком. Таким запомнил его Н.В. Алексеенко, который писал: 
Бедельбаева М.В. «Рыцарь без страха и упрёка»

«Есть и будут еще блестящие исследования. Обогатилась и будет обогащаться наука новыми открытиями. Но не будет другого Сергея Сергеевича. Не в том смысле, что он был исключительно выдающимся ученым, а в том, что он был самим собой. Славным товарищем, умещавшимся в таком же спальнике, как и все члены экспедиции, евшим одну с нами кашу.
Распевавшим во все горло те же песни, часто собственного сочинения. Он умел делать открытия, но начисто лишен был способности - даже мысленно! - становиться на пьедестал» [Алексеенко, 2011, с. 82].

Давайте таким запомним

С.С. Черникова и мы.

\section{Список основных публликаций С.С. Черникова}

\section{Авторефераты:}

Древняя металлургия и горное дело Западного Алтая. Тезисы кандидатской диссертации, защищённой в Учёном совете ЛО ИИМК АН СССР 03.IV.1947 // КСИИМК. 1948. Вып. 23. С. 96-100.

Восточный Казахстан в эпоху неолита и бронзы: автореф. дис. ... докт. ист. наук. М.: ИА АН СССР, 1970. 60 с.

\section{Монографии:}

Древняя металлургия и горное дело Западного Алтая. Алма-Ата: Изд-во АН КазССР, 1949. 112 с.

Восточный Казахстан в эпоху бронзы // МИА СССР. 1960. № 88. 272 с.

Загадка Золотого кургана. Где и когда зародилось «скифское искусство». М.: Наука, 1965. 190 с.

\section{Статьи:}

Древняя добыча меди в верховьях Иртыша // КСИИМК. 1939. Вып. 2. С. 22-23.

Работы в Казахстане по обследованию древних рудных разработок // КСИ-

ИМК. 1940. Вып. 2. С. 31-32.

Восточно-Казахстанская область. Калбинский и Нарымский хребты. 1935 г. // Археологические исследования в РСФСР 1934-1936 гг.: Краткие отчёты и сведения. М.; Л.: Изд-во АН СССР, 1941. С. 292-296.

Наскальные изображения Верховий Иртыша // СА. 1947. Т. 9. С. 251-282.

Древнее горное дело в районе г. Степняк (По материалам обследования 1938 г.)

// Изв. АН КазССР. 1948а. № 46. Сер. археол. Вып. 1. С. 13-32.

Древняя металлургия и горное дело Западного Алтая // КСИИМК. $1948 б$.

Вып. 23. С. 96-100.

Отчёт о работах Восточно-Казахстанской археологической экспедиции 1947

года // Изв. АН КазССР. 1949. № 67. Сер. археол. Вып. 2. С. 37-58.

Основные проблемы археологического изучения Казахстана // Изв. АН КазССР. 1950. № 77. Сер. историч. Вып. 5. С. 63-70.

Восточно-Казахстанская экспедиция // КСИИМК. 1951. Вып. 37. С. 144-150.

К вопросу о составе древних бронз Казахстана // СА. 1951. Т. XV. С. 140-161.

Находки палеолитических стоянок в Восточном Казахстане // Вестник АН КазССР. 1951. № 12 (81). С. 63-70.

Отчёт о работах Восточно-Казахстанской экспедиции 1948 г. // Изв. АН КазССР. 1951. № 108. Сер. археол. Вып. 3. С. 64-80. 
Восточно-Казахстанская экспедиция 1950 г. // КСИИМК. 1952. Вып. 48. C. 81-92.

Пещера Конур-Аулие // Изв. АН КазССР. 1953. Сер. геол. Вып. 16. С. 121-124.

Поселения эпохи бронзы в Северном Казахстане // КСИИМК. 1954. Вып. 53. C. 29-49.

Некоторые итоги работы Восточно-Казахстанской (Бухтарминской) археологической экспедиции (на сессии Отделения исторических наук и пленума ИММК, посвящённых итогам археологических исследований 1955 г.). М.; Л.: б/и, 1956. C. 23-26.

О работах Восточно-Казахстанской экспедиции // КСИИМК. 1956. Вып. 64. C. $43-60$.

К изучению древней истории Восточного Казахстана // КСИИМК. 1957. Вып. 69. С. 12-21.

Роль андроновской культуры в истории Средней Азии и Казахстана // КСИЭ. 1957. Вып. 26. С. 28-33.

Работы Восточно-Казахстанской археологической экспедиции в 1956 году // КСИИМК. 1959. Вып. 73. С. 99-106.

О термине «ранние кочевники» // КСИИМК. 1960. Вып. 80. С. 17-21.

Памятники архитектуры ойрат-калмыков // Записки Калмыцкого научноисследовательского института, языка, литературы и истории. Элиста: б/и, 1960. Вып. 1. С. 115-134.

\section{Рецензия:}

Археологическая карта Казахстана (реестр памятников и альбом карт). Академия наук Казахской ССР. Институт истории, археологии и этнографии. Изд-во АН КазССР. Алма-Ата, 1960. Составители карты: Е.И. Агеева. К.А. Акишев (отв. ред.), Г.А. Кушаев, А.Г. Максимова, Т.Н. Сенигова. [Рецензия] // СА. 1963. № 1. C. 314-317.

\section{ЛИТЕРАТУРА}

1. Академическая археология на берегах Невы (от РАИМК до ИИМК РАН, 1919-2014 гг.). СПб.: «Дмитрий Буланин», 2013. 416 с., 88 илл.

2. Акишев К.А. Археология в Казахстане за советский период // СА. 1967. № 4. C. $62-78$.

3. Алексеенко Н.В. Наш Сергей Сергеевич Черников // Краеведы Восточного Казахстана: пособие / Сост. Жиенбекова Ж.М., Захарова Т.Б. Усть-Каменогорск: Издательский отдел Центральной городской библиотеки, 2011. C. 80-83 [URL: https:// ru.calameo.com/read/002950357c7f3348ca0a9] (дата обращения: 16.08.2019 г.).

4. Бейсенов А.З., Джумабекова Г.С., Базарбаева Г.А. Путь к изучению древностей центра страны: история создания первой археологической экспедиции Казахской Академии наук // Археологическое наследие Центрального Казахстана: изучение и сохранение: сб. научн. ст., посвящ. 70-летию организации ЦКАЭ Академии наук Казахстана. Алматы: НИЦИА «Бегазы-Тасмола», 2017. Т. 1. С. 11-64.

5. Бентович И.Б. Сектор Средней Азии и Кавказа в 1963 и 1964 гг. // КСИА. 1966. Вып. 108. С. 135-138.

6. Бентович И.Б. Работа сектора Средней Азии и Кавказа в 1967 и 1968 гг. // КСИА. 1970. Вып. 122. С. 122-124.

7. Гурина Н.Н. О работе сектора Средней Азии и Кавказа ЛОИИМК в 1956 г. // КСИА. 1958. Вып. 72. С. 113-116. 
8. Длужневская Г.В. Археологические исследования в Центральной Азии и Сибири в 1859-1959 гг. (по документам Научного архива Института истории материальной культуры РАН). СПб.: ЭлекСис, 2011. 296 с.

9. Кадырбаев М.К. Сергей Сергеевич Черников: [1909-1976. Некролог] // Изв. АН КазССР. Сер. обществ. наук. 1976. № 6. С. 88-89.

10. Кожин П.М. Всесоюзное совещание по вопросам андроновской культуры // КСИА. 1966. Вып. 106. С. 118-120.

11. Кузьмина Е.Е. Классификация и периодизация памятников андроновской культурной общности. Актобе: ПринтА, 2008. 358 с., илл.

12. Кызласов Л.Р. Слово об Алеке Маргулане // Археологическое наследие Центрального Казахстана: изучение и сохранение: сб. научн. ст., посвящ. 70-летию организации ЦКАЭ Академии наук Казахстана. Алматы: НИЦИА «Бегазы-Тасмола», 2017. T. 1. C. 70-75.

13. Максимова А.Г. Эпоха бронзы Восточного Казахстана // ТИИАЭ АН КазССР. 1959. Т. 7. С. 86-150.

14. Наградной лист C.C. Черникова. URL: https://pamyat-naroda.ru/heroes/ podvig-chelovek_nagrazhdenie36765132/ (дата обращения: 16.08.2019 г.).

15. Рогожинский А.Е. Труженица археологии (А.Г. Максимова) // Археологическое наследие Центрального Казахстана: изучение и сохранение: сб. научн. ст., посвящ. 70-летию организации ЦКАЭ Академии наук Казахстана. Алматы: НИЦИА «Бегазы-Тасмола», 2017. Т. 1. С. 146-148.

16. Скифо-сибирский звериный стиль в искусстве народов Евразии: Материалы Третьей конференции по скифо-сибирской археологии. М.: Наука, 1976. 272 с.

17. Скоробогатов Д.И. Однополчане (Военные мемуары). М.: Воениздат, 1976. 239 c. URL: http://militera.lib.ru/memo/russian/skorobogatov_di/03.html (дата обращения: 16.08.2019 г.).

18. Сорокин В.С. Рец.: С.С. Черников. Восточный Казахстан в эпоху бронзы // СЭ. 1962. Вып. 1. С. 124-130.

19. Успехи среднеазиатской археологии. 1972. Вып. 1. 96 с.

20. Хлобыстина М.Д. Работа сектора Средней Азии и Кавказа в 1969-1973 гг. // КСИА. 1976. Вып. 147. С. 126-129.

21. Чалая Л.А. Неолит Северо-Восточного и Центрального Казахстана: автореф. дис. ... канд. ист. наук. М.: б/и, 1971. 22 с.

22. Черников С.С. Восточный Казахстан в эпоху бронзы // МИА СССР. 1960. № $88.272 \mathrm{c}$.

23. Черников С.С. Археологическая карта Казахстана (реестр памятников и альбом карт). АН КазССР. Институт истории, археологии и этнографии. Изд-во АН КазСССР, Алма-Ата, 1960. Сост. карты: Е.И. Агеева. К.А. Акишев (отв. ред.), Г.А. Кушаев, А.Г. Максимова, Т.Н. Сенигова // СА. 1963. № 1. С. 314-317.

24. Черников С.С. Загадка Золотого кургана. Где и когда зародилось «скифское искусство». М.: Наука, 1965. 190 с.

\section{Сведения об авторе:}

Бедельбаева Марина Васильевна - кандидат исторических наук, заведующая музеем археологии и этнографии, Сарыаркинский археологический институт, Карагандинский государственный университет им. академика Е.А. Букетова (г. Караганды, Казахстан); bmv_1967@mail.ru 


\title{
«ЕШ НӘРСЕДЕН ТАЙСАЛМАЙТЫН ЕР МІНЕЗДІ, АДАМГЕРШІЛІК ПЕН АР-НАМЫСТЫ СЕРІ» \\ (С.С. Черниковтың туғанына 110-жыл)
}

\author{
М.В. Беделбаева
}

Мақала осы жылы туылғанына 110 жыл толатын белгілі археолог, Шығыс Қазақстанның ежелгі тарихын зерттеген С.С. Черниковтың (1909-1976) өмірі мен ғылыми қызметіне арналған. Ол 1947 жылдан бастап өмірінің соңғы күндеріне дейін (1972 ж.) Шығыс Қазақстан археологиялық экспедициясының тұрақты жетекшісі болды. С.С. Черниковтың іргелі зерттеулері осы өңірдің қола дәуірінің ескерткіштерінің мерзімін және ежелгі қоғамдардың әлеуметтік-экономикалық тарихының жалпы сұлбасын анықтауға елеулі үлес қосты. Оның ең ірі ашуы және маңызды ескерткіші, әлемдік археология қорына енген Шілікті аңғарындағы танымал «Алтын қорғанды» қазуы болып табылады.

Түйін сөздер: археология, С.С. Черников, Шығыс Қазақстан, қола кезеңі, ежелгі металургия, ежелгі көшпенділер, қорған

\section{«KNIGHT WITHOUT FEAR AND REPROACH» \\ (To the 110 - th anniversary of birth of Sergei Chernikov)}

\section{M.V. Bedelbayeva}

The article is devoted to life and scientific activity of S.S. Chernikov (1909-1976)a famous archaeologist, researcher of the ancient history of East Kazakhstan, whose 110th anniversary is celebrated this year. From 1947 to the 1972 he was a permanent head of the East Kazakhstan archaeological expedition. Fundamental works of S.S. Chernikov made a significant contribution to the development of chronology of the Bronze age sites of the region and to the definition of General contours of the socio-economic history of ancient societies. A major discovery and an important site included in the world Fund of archaeology, began his excavation of the famous "Golden mound" in Chilikty valley.

Keywords: archaeology, S. Chernikov, East Kazakhstan, Bronze era, ancient metallurgy, early nomads, mound

\section{REFERENCES}

1. Akademicheskaya arheologiya na beregah Nevy (Academic archeology at the Neva river). 2013. Saint Petersburg: "Dmitry Bulanin" Publ. (in Russian).

2. Akishev, K. A. 1967. In Sovetskaya arheologiya (Soviet archaeology), 4, 62-78 (in Russian).

3. Alekseenko, N. V. 2011. In Jienbekova, Zh. M., Zaharova, T. B. (comp.) Kraevedy Vostochnogo Kazahstana (Local Lore East Kazakhstan). Ust-Kamenogorsk (in Russian).

4. Beisenov, A. Z., Jumabekova, G. S., Bazarbayeva, G. A. 2017. In Beisenov, A. Z., Loman, V. G. (eds.). Arheologicheskoe nasledie Centralnogo Kazahstana (Archaeological Heritage of Central Kazakhstan), 1, 11-64. Almaty: "Begazy-Tasmola" Publ. (in Russian).

5. Bentovich, I. B. 1966. In Kratkie soobshcheniya Instituta arheologii (Brief Communications from the Institute of Archaeology), 108, 135-138 (in Russian).

6. Bentovich, I. B. 1970. In Kratkie soobshcheniya Instituta arheologii (Brief Communications from the Institute of Archaeology), 122, 122-124 (in Russian).

7. Gurina, N. N. 1958. In Kratkie soobshcheniya Instituta arheologii (Brief Communications from the Institute of Archaeology), 72, 113-116 (in Russian).

8. Dluzhnevskaya, G. V. 2011. Arheologicheskie issledovaniya v Centralnoi Azii i Sibiri v 1859-1959 gg. (Archaeological research in Central Asia and Siberia in 18591959). Saint Petersburg: "ElekSis" Publ. (in Russian).

9. Kadyrbayev, M. K. 1976. In Izvestiya Akademii nauk KazSSR. Ser. obshchestv. nauk (News of the Academy of Sciences of the KazakhSSR. Social Sciences Series), 6, 88-89 (in Russian). 
10. Kozhin, P. M. 1966. In Kratkie soobshcheniya Instituta arheologii (Brief Communications from the Institute of Archaeology), 106, 118-120 (in Russian).

11. Kuzmina, E. E. 2008. Klassifikaciya i periodizaciya pamyatnikov andronovskoi kulturnoi obshchnosti (Classification and periodization of monuments of the Andronovo cultural community). Aktobe: "PrintA" Publ. (in Russian).

12. Kyzlasov, L. R. 2017. In Beisenov, A. Z., Loman, V. G. (eds.). Arheologicheskoe nasledie Centralnogo Kazahstana (Archaeological Heritage of Central Kazakhstan), 1, 70-75. Almaty: "Begazy-Tasmola" Publ. (in Russian).

13. Maksimova, A. G. 1959. In Trudy Instituta istorii, arheologii i etnografii Akademii nauk KazSSR (Proceedings of the Institute of History, Archeology and Ethnography of the Academy of Sciences of the Kazakh SSR), 7, 86-150 (in Russian). nie36765132/

14. URL: https://pamyat-naroda.ru/heroes/podvig-chelovek_nagrazhde-

15. Rogozhinskiy, A. E. 2017. In Beisenov, A. Z., Loman, V. G. (eds.). Arheologicheskoe nasledie Centralnogo Kazahstana (Archaeological Heritage of Central Kazakhstan), 1, 146-148. Almaty: "Begazy-Tasmola" Publ. (in Russian).

16. Skifo-sibirskii zverinyi stil v iskusstve narodov Evrazii (Scythian-Siberian animal style in the art of the peoples of Eurasia). 1976. Moscow: "Nauka" Publ. (in Russian).

17. Skorobogatov, D. I. 1976. Odnopolchane. (Voennye memuary) (Fellow soldiers (War memoirs)). Moscow: "Voenizdat" Publ. URL: http://militera.lib.ru/memo/russian/ skorobogatov_di/03.html (in Russian).

18. Sorokin, V. S. 1962. In Sovetskaya etnografiya (Soviet ethnography), 1, 124130 (in Russian).

19. Uspekhi sredneaziatskoi arheologii (Successes of Central Asian archaeology), 1972, 1 (in Russian).

20. Hlobystina, M. D. 1976. In Kratkie soobshcheniya Instituta arheologii (Brief Communications from the Institute of Archaeology), 147, 126-129 (in Russian).

21. Chalaya, L. A. 1971. Neolit Severo-Vostochnogo i Centralnogo Kazahstana: avtoref. dis. ... kand. ist. nauk. (Neolithic of North-East and Central Kazakhstan: author. dis. ... cand. hist. sciences). Moscow (in Russian).

22. Chernikov, S. S. 1960. In Materialy i issledovaniya po arheologii SSSR (Materials and research on archaeology of the USSR), 88 (in Russian).

23. Chernikov, S. S. 1963. In Sovetskaya arheologiya (Soviet archaeology), 1, 314 317 (in Russian).

24. Chernikov, S. S. 1965. Zagadka Zolotogo kurgana. Gde i kogda zarodilos «skifskoe iskusstvo" (The mystery of the Golden Barrow. Where and when did "Scythian art" originate?). Moscow: "Nauka" Publ. (in Russian).

\section{About the Author:}

Bedelbayeva Marina V. Candidate of historical sciences, director, Archaeology and ethnography museum, Saryarka archaeological Institute, academician E.A. Buketov Karagandy State University, Karagandy, Kazakhstan; bmv_1967@mail.ru

\footnotetext{
Мүдделер қақтығысы туралы ақпаратты ашу. Автор мүдделер қақтығысының жоқтығын мәлімдейді. / Раскрытие информации о конфликте интересов. Автор заявляет об отсутствии конфликта интересов. / Disclosure of conflict of interest information. The author claim no conflict of interest.

Мақала туралы ақпарат / Информация о статье / Information about the article. Редакцияға түсті / Поступила в редакцию / Entered the editorial office: 16.08.2019. Рецензенттер мақұлдаған / Одобрено рецензентами / Approved by reviewers: 23.08.2019. Жариялауға қабылданды / Принята к публикации / Accepted for publication: 30.08.2019.
} 